\title{
A Kryptoperidiniaceae species (Dinophyceae: Peridiniales) blooming in coastal Yucatan waters, Gulf of Mexico
}

\author{
Yuri B. Okolodkov ${ }^{1}$, Fany del Carmen Merino-Virgilio ${ }^{2}$, \\ Dora A. Huerta-Quintanilla², Ismael Gárate-Lizárraga ${ }^{3}$, \\ Karen A. Steidinger ${ }^{4}$, Ana C. Aguilar-Trujillo ${ }^{2}$, Jorge A. \\ Herrera-Silveira ${ }^{2}$, Silvia Espinosa-Matías ${ }^{5}$, Alejandro \\ Martínez-Mena ${ }^{5}$ \\ ${ }^{1}$ Instituto de Ciencias Marinas y Pesquerias, Universidad Veracruzana (ICIMAP- \\ UV), Laboratorio de Botánica Marina y Planctología, Boca del Río, Veracruz, \\ Mexico \\ ${ }^{2}$ Centro de Investigación y Estudios Avanzados - Instituto Politécnico Nacional \\ (CINVESTAV-IPN), Unidad Mérida, Departamento de Recursos del Mar, Mérida, \\ Yucatán, Mexico \\ ${ }^{3}$ Instituto Politécnico Nacional, Centro Interdisciplinario de Ciencias Marinas \\ (CICIMAR-IPN), Departamento de Plancton y Ecología Marina, La Paz, Baja \\ California Sur, Mexico \\ ${ }^{4}$ Fish and Wildlife Research Institute, Florida Fish and Wildlife Conservation \\ Commission, St. Petersburg, Florida, USA \\ ${ }_{5}^{5}$ Facultad de Ciencias, Universidad Nacional Autónoma de México, México, D.F., \\ Mexico
}

| Submitted February 27, 2020 | Accepted April 15, 2020 |

\section{Summary}

A small, photosynthetic Peridiniales species caused an intense bloom (up to $3.75 \times 10^{7}$ cells $\cdot 1^{-1}$ ) in the marina of Sisal on the northern Yucatan Peninsula coast, SE Gulf of Mexico, in August 2010. The salinity was 32.4, and the water temperature was 29.5 ${ }^{\circ} \mathrm{C}$. The cells were $12.5-23.7 \mu \mathrm{m}$ long $(19.02 \pm 2.03 \mu \mathrm{m}), 8.7-18.7 \mu \mathrm{m}$ wide $(15.45 \pm$ $2.19 \mu \mathrm{m}$ ) and $7.5-12.5 \mu \mathrm{m}$ deep (dorsoventral length; $9.63 \pm 1.21 \mu \mathrm{m}$ ), the length/ width ratio was $1.17 \pm 0.13$ and the width/depth ratio $1.83 \pm 0.22(\mathrm{n}=200)$. The species had a thecal plate formula of Po, X, cp, 4', 2a, 6", 5c, PC, 4s, 5"', 2"”. The taxon was assigned to the family Kryptoperidiniaceae, although a second (eukaryotic) nucleus was not observed, sharing its thecal features with both Kryptoperidinium and Durinskia. In subsequent years, it was occasionally found at other sites along the Yucatan coast and possibly represents a recent invasion of the southern Gulf of Mexico, preferring semi-enclosed water bodies.

Key words: algal blooms, dinoflagellates, Kryptoperidiniaceae, microalgae, phytoplankton, scanning electron microscopy, thecal morphology

doi:10.21685/1680-0826-2020-14-2-2 


\section{Introduction}

In the coastal waters of the northern Yucatan Peninsula, in the southeastern Gulf of Mexico, numerous pelagic algal blooms have been recorded in the 21 st century; at least 35 species, almost exclusively diatoms and dinoflagellates, caused them (MerinoVirgilio et al., 2014). Among dinoflagellates, species of Prorocentrum Ehrenb., Peridinium Ehrenb., Scrippsiella Balech ex Loeblich III and Pyrodinium L. Platt, as well as the dinoflagellate preliminarily identified as Kryptoperidinium cf. foliaceum (F. Stein) Lindemann, have caused recurrent blooms.

The latter, although not identified to the genus level, was ascribed to the recently reestablished family Kryptoperidiniaceae according to Gottschling et al. (2017) and includes the genera Kryptoperidinium Lindemann, Blixaea Gottschling, Durinskia Carty et Cox, Galeidinium M. Tamura et T. Horiguchi and Unruhdinium Gottschling. This taxonomic group was called 'dinotoms' due to the presence of two mitochondrial genomes, one of the host dinoflagellate and another one from an endosymbiotic diatom (Imanian et al., 2011); cells harbour the chloroplasts of diatom origin from the genera Chaetoceros Ehrenb., Cyclotella (Kütz.) Bréb., Discotella V. Houk et R. Klee or Nitzschia Hassall (Yamada et al., 2017). The dinoflagellate genus Dinothrix Pascher may also belong to group (Gottschling et al., 2017). This group contains both planktonic and benthic marine, brackish and freshwater species, and some of them are common or abundant or even cause non-toxic blooms. Of them, it is Blixaea quinquecornis (T.H. Abé) Gottschling (=Peridinium quinquecorne, in part) that has caused most blooms in temperate and tropical coastal marine waters (Horstmann, 1980; Rodríguez-Gómez et al., 2019; see references in Okolodkov et al., 2016). In brackish and freshwater environments, Kryptoperidinium foliaceum has been observed in the highest abundances (Daghor et al., 2015; Alkawri, 2016; Lira et al., 2017). Recently, it was also found as blooming in a hypersaline water body in the northwestern Persian Gulf (Saburova et al., 2012b). Among Durinskia species, D. baltica is the most studied species. However, it has rarely been mentioned as blooming; it caused early spring blooms in a eutrophic freshwater body in central Mexico (Lira et al., 2017). Durinskia capensis was observed producing blooms in tidal pools in South Africa (Pienaar et al., 2007).

The objective of this study was to identify the causative species and to describe its morphology.

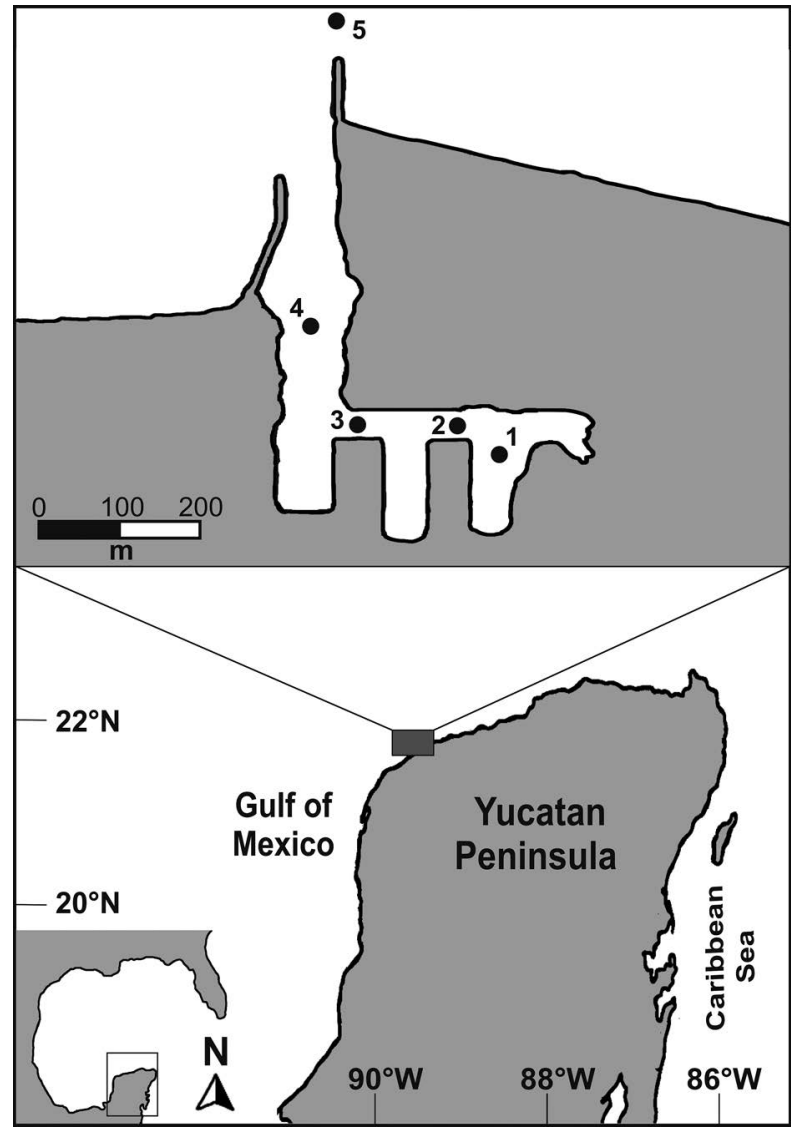

Fig. 1. Sampling sites (1-5) in the marina of Sisal, Yucatan Peninsula, in August 2010.

\section{Material and methods}

\section{STUDY AREA}

The study area is characterized by a dry, warm climate. At Dzilam de Bravo (Dzilam, hereafter), water temperature varies between $22.3^{\circ} \mathrm{C}$ (February) and $31.0-32.0{ }^{\circ} \mathrm{C}$ (June-September) and salinity between 29.6 (April) and 37.3 (May). There are no rivers along the Yucatan coast. Ground water discharge causes negligible salinity variations. Three seasons can be distinguished: a dry season from March to early June, a rainy season from June to October and the "nortes" (northerly winds) season with short periods of storms and strong winds coming from the north from November to February (Herrera-Silveira, 1993).

SAMPLING, FIXATION AND MEASUREMENTS OF ENVIRONMENTAL VARIABLES

On 18 August 2010, during the monitoring of benthic dinoflagellates along the coast of the Yucatan 


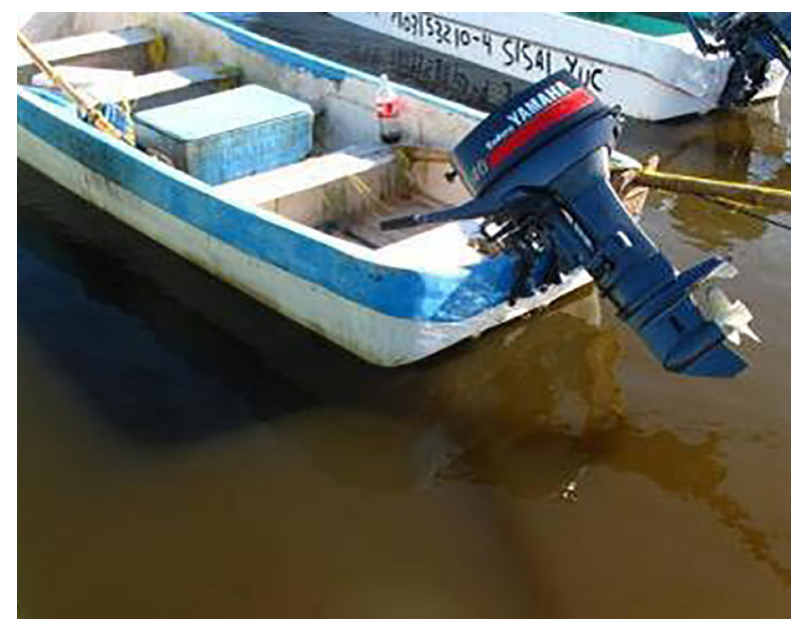

Fig. 2. A bloom event in the marina of Sisal, Yucatan Peninsula, on 18 August 2010.

Peninsula, SE Gulf of Mexico, in the marina of the small fishery settlement Sisal (Fig. 1), a dense dinoflagellate bloom was observed; station (st.) 1 was located at $21^{\circ} 9^{\prime} 40.22^{\prime \prime} \mathrm{N}, 90^{\circ} 2^{\prime} 42.71^{\prime \prime} \mathrm{W}$. The water color was greenish-brown (Fig. 2), typical of chlorophyll-containing microalgae. Four seawater samples were taken in various parts of the marina and one beyond it with a bottle from the surface layer; samples were fixed with $37 \%$ formalin to a final concentration of $4 \%$. The measured depth was $2.5 \mathrm{~m}$, and visually, the bloom event was restricted to the marina.

\section{LIGHT AND SCANNING ELECTRON MICROSCOPY}

Cells were counted in 40 to 100 fields of view in two aliquots of each sample in a 1-ml SedgwickRafter chamber using an Olympus CK2 inverted microscope (Olympus Optical Co., Ltd., Japan) equipped with a $40 \times$ objective. Light micrographs of empty thecae were taken using an Olympus AX70 PROVIS compound microscope (Olympus Optical Co., Ltd., Japan) equipped with phasecontrast objectives and a Media Cybernetics Evolution MP digital camera (Media Cybernetics, Inc., Silver Spring, MD, USA) and QCapture Pro (version 5.1) software (Teledyne QImaging, Surrey, $\mathrm{BC}$, Canada). To examine the thecae in greater detail, the specimens were examined in a JEOL JSM-7600F (JEOL, Ltd., Tokyo, Japan) scanning electron microscope (SEM) at a working distance of $15 \mathrm{~mm}$, a voltage of $5.0 \mathrm{kV}$ and a low secondary electron detector (LEI) after a preliminary wash in distilled water followed by dehydration in a series of ethanol solutions of increasing concentration $(30,50,70,90$ and 100\%). Specimens were then air dried on 0.5 " aluminium mounts and sputter coated with gold-palladium using a Polaron SC7640 High Resolution Sputter Coater (Quorum Technologies, Newhaven, SXE, UK). Line drawings of the thecal plate arrangement were made based on SEM micrographs. Various cells were examined with a Carl Zeiss Axio Imager.A1 fluorescence microscope (Oberkochen, Germany) with an ApoTome attachment (Axio Imager Z1 stand). The formalin-fixed cells were stained with $0.2 \%$ acetocarmine for testing for the presence of nuclei (dinokaryon and/ or endosymbiont nucleus).

\section{Results}

\section{MORPHOLOGICAL DESCRIPTION}

The described species was classified according to Fensome et al. (1993) and Kretschmann et al. (2018).

Phylum Dinoflagellata (Bütschli) Fensome, Taylor, Norris, Sarjeant, Wharton et Williams

Subphylum Dinokaryota Fensome, Taylor, Sarjeant, Wharton et Williams, 1993

Class Dinophyceae Pascher, 1914

Subclass Peridiniphycidae Fensome, Taylor, Sarjeant, Wharton et Williams, 1993

Order Peridiniales Haeckel, 1894

Suborder Peridiniineae Poche, 1913

Family Kryptoperidiniaceae Lindemann, 1926

Description. The causative agent of the bloom event was a small nanoplanktonic thecate dinoflagellate ascribed by us to the order Peridiniales. Examination of various cells with the use of the ApoTome equipment confirmed the presence of several dozen discoid chloroplasts of greenish color that occupied nearly all the space between the nucleus and theca. In all cells, only a dinokaryon (one per cell) was observed (Fig. 3); it was elongated and occupied a subcentral position. The cells were 12.5$23.7 \mu \mathrm{m}$ long $(19.02 \pm 2.03 \mu \mathrm{m}), 8.7-18.7 \mu \mathrm{m}$ wide $(15.45 \pm 2.19 \mu \mathrm{m})$ and $7.5-12.5 \mu \mathrm{m}$ thick $(9.63 \pm 1.21$ $\mu \mathrm{m})$, the length/width ratio was $1.17 \pm 0.13$ and the width/depth ratio $1.83 \pm 0.22(n=200)$. Cells in general were ovoid, and at the light microscope level the theca was smooth, with the epitheca larger (up to 1.5 times) and slightly wider than the hypotheca 

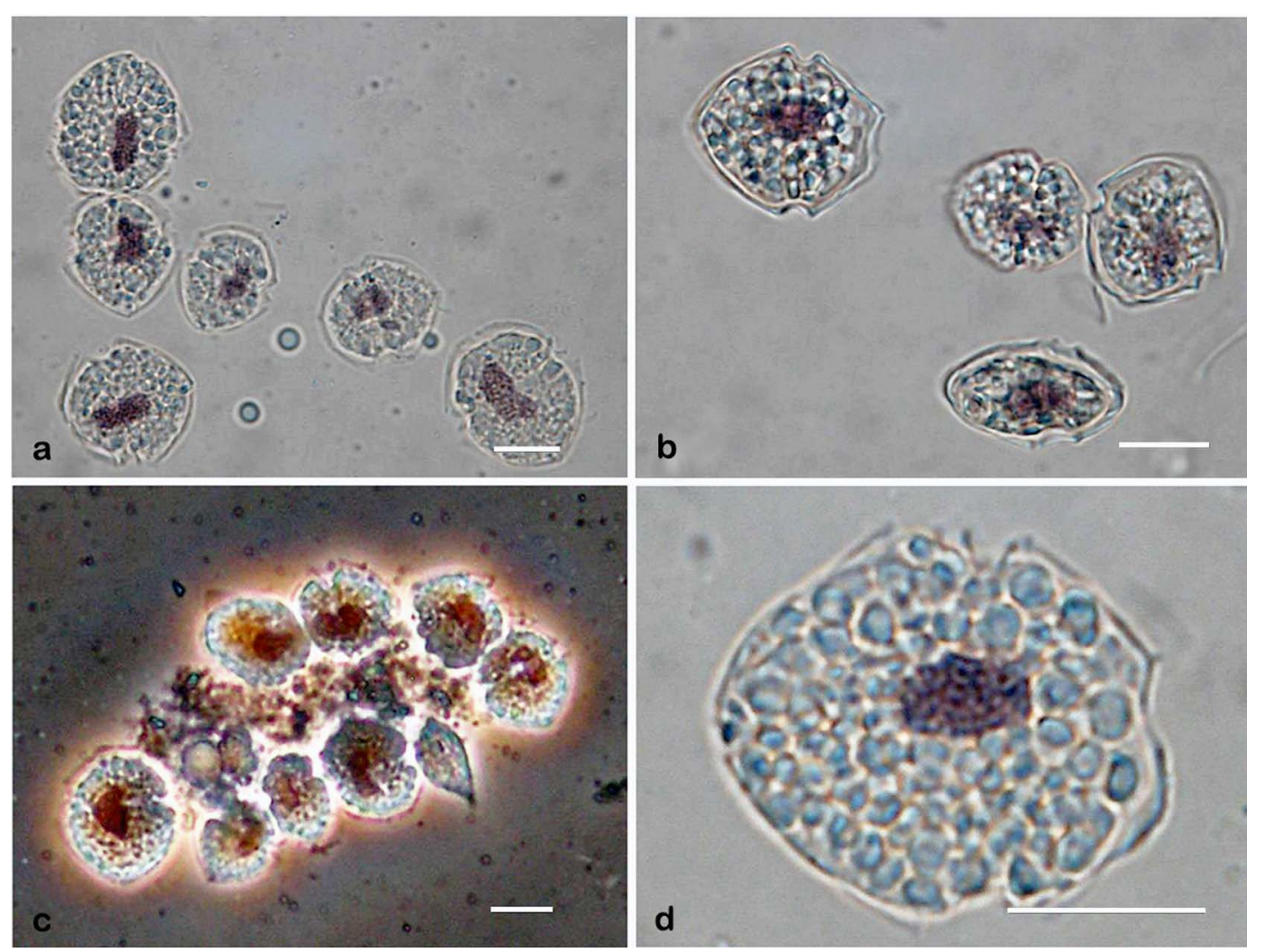

Fig. 3. Cells of the Kryptoperidiniaceae species from Yucatan waters fixed with formalin and observed with a light microscope: (a, b and d) bright field, (c) phase contrast. In all the cells the only nucleus (dinokaryon) stained with acetocarmine occupies a subcentral position. In Fig. d, the spiralized chromosomes are clearly visible. Each cell has several dozen discoid chloroplasts that occupy almost all the space between the nucleus and theca. Scale bar: $10 \mu \mathrm{m}$.

and strongly compressed dorsoventrally. Thecal plate formula: Po, X, cp, 4', 2a, 6”, 5c, PC, 4s, 5", 2" " (Figs 4, 5). Epitheca with convex sides, slightly angulated in the middle part in ventral or dorsal view. Apical pore complex shifted to the left side of the epitheca (Figs 6 b, e, 7 a), elongated and narrow, with a flange except at the juncture of the Po and the X plates on the ventral surface. The X, or "canal" plate contacted the 1' plate and was a small rectangle (Fig. $7 \mathrm{~d}, \mathrm{f}$ ). The Po plate was elongated, slightly wider on the dorsal side, narrowing ventrally, bordered with the elevated margins of the 2' and 4' plates, with an elongated pore and a cover plate. Plate 1' was of ortho type, wide, asymmetrically kite-shaped, with the lateral angles closer to the apex than to the cingulum, without any large margin pore (Figs 6 a, b, e, 7 a). Plate 3' on the dorsal side of the epitheca was pentagonal or quadrangular, narrow or wide, asymmetrical, the smallest among the apicals, and slightly shifted to the left (Fig. 7 d, f). Two relatively large anterior intercalary plates were present (Fig. $7 \mathrm{~d}-\mathrm{f}$ ); the 1a is slightly larger than 2a. Among the precingular plates, the plates adjacent to the 1' plate (6" and 1") were the largest and the longest (Fig. $6 \mathrm{a}, \mathrm{b}$ ), and the 3" plate (dorsal) was the smallest. The 4 " contacted both anterior intercalary plates (Fig. 7 f). Rarely, the 3" plate was divided into two, forming the 4" plate; in this case there were seven precingular plates. Cingulum strongly cavozone, with very narrow cingular lists without ribs, relatively wide (14 to $17 \%$ of the cell total length), descending, displaced 0.75 to one cingulum width (Figs $6 \mathrm{a}-\mathrm{c}, \mathrm{e}, 7 \mathrm{a}$ ). The 1c plate was relatively narrow and trapezoidal, with its narrower side attached to the hypotheca (1", plate). The sulcus was shallow and relatively narrow, almost reaching the antapex and not extending into the epitheca. The sulcus had a finger-shaped depression in its distal part and a trapezoidal lobe of the pore cover plate (PC) (Fig. $6 \mathrm{c}, \mathrm{d}$ ). The PC was anchored to the 5th cingular plate but was free on its left side. Some authors have interpreted the PC 

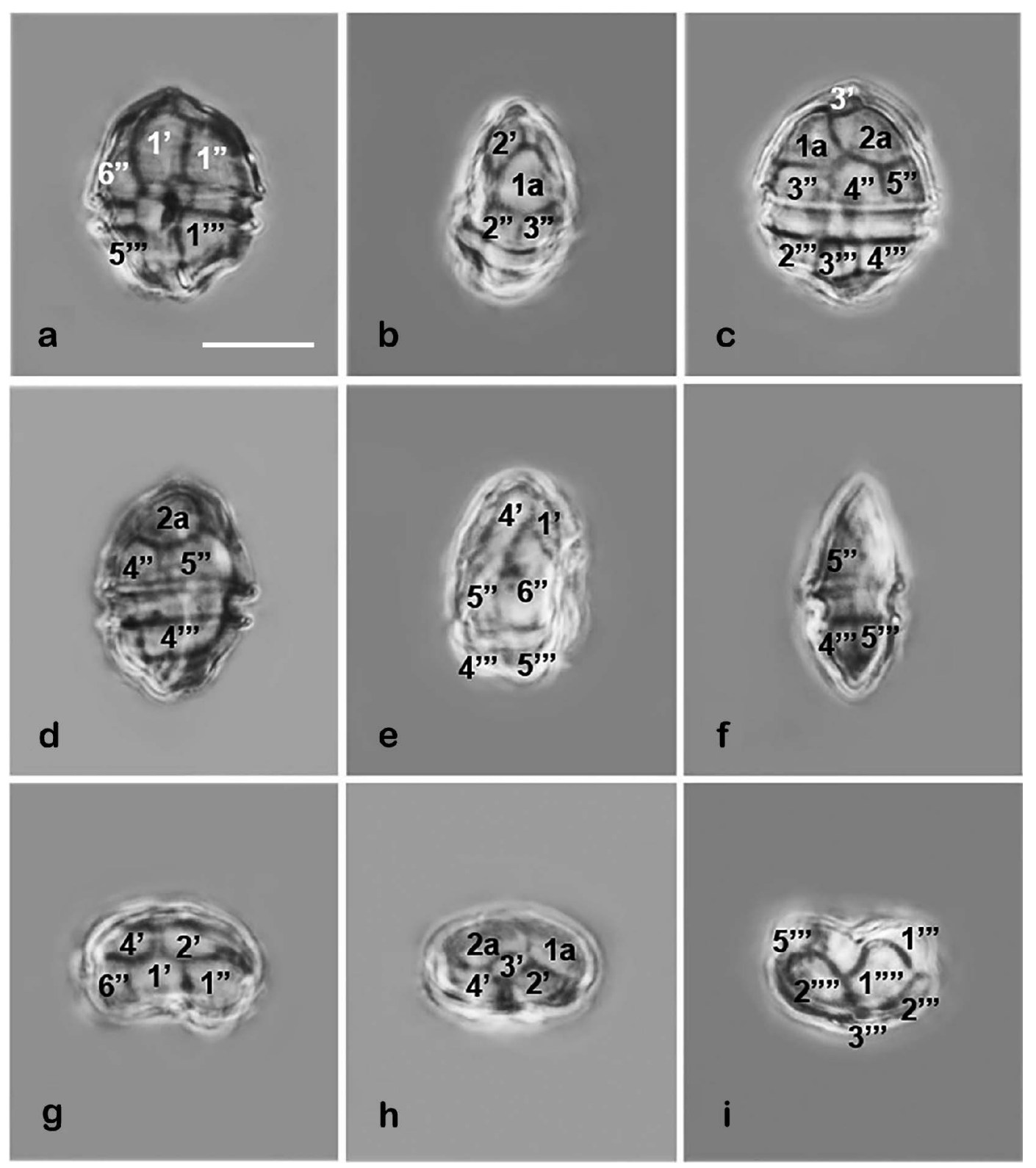

Fig. 4. Thecae of the Kryptoperidiniaceae species from Yucatan waters under a phase-contrast microscope: (a) ventral view, (b) left-side-apical view, (c) dorsal view, (d) right-side-dorsal view, (e) right-side-apical view, (f) right-side view, (g) apical view, (h) apical-dorsal view, (i) antapical view. Scale bar: $10 \mu \mathrm{m}$.

as a fin extension of the underlying s.d. plate. The transverse flagellar pore was rimmed and noticeable (Fig. 6 c, d, f). Plate s.p. was subovoid, and it was a little longer than it was wide (Fig. 6 c). Hypotheca with slightly convex to straight sides in ventral view; its right side was slightly longer than the left. Antapex slightly convex, flattened or with a very shallow depression, usually with the crests radiating in a longitudinal direction, some of them terminating with short, robust spines of $0.17-0.20 \mu \mathrm{m}$ long (Fig.
7 b). Plate surface delicately ornamented with pores and furrows that end in pores or in older specimens end in protuberances. Ejectosome pores, possibly trichocyst or mucocyst pores, present. Rimmed circles $0.17-0.20 \mu \mathrm{m}$ in diameter surrounded ejectosome pores, forming a linear row along both sides of the cingulum and sparsely dispersed along the plates, including the cingular and sulcal ones (well distinguished in Figs 5 c, 6 a, c).

Habitat: coastal marine, planktonic. 


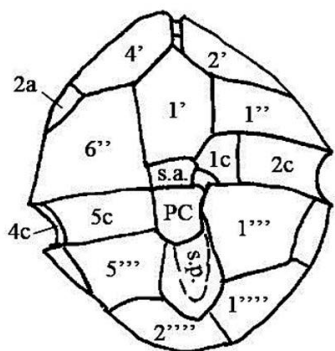

a

Fig. 5. A scheme illustrating the thecal pattern of the Kryptoperidiniaceae species: (a) cell in ventral view, (b) cell in dorsal view. Scale bar: $10 \mu \mathrm{m}$.

\section{ENVIRONMENTAL VARIABLES AND CELL ABUNDANCES}

The physical-chemical characteristics at st. 1 were as follows: water temperature $29.5^{\circ} \mathrm{C}$, salinity 32.4, dissolved oxygen $0.77 \mathrm{mg} \cdot 1^{-1}$, nitrates 1.88 $\mu \mathrm{mol} \cdot 1^{-1}$, nitrites $1.17 \mu \mathrm{mol} \cdot 1^{-1}$, ammonium 5.91 $\mu \mathrm{mol} \cdot 1^{-1}$, urea $0.76 \mu \mathrm{mol} \cdot 1^{-1}$, orthophosphates $1.28 \mu \mathrm{mol} \cdot 1^{-1}$ and silicates $97.22 \mu \mathrm{mol} \cdot 1^{-1}$. Chl- $a$ concentration in the water column reached 5.25 $\mathrm{mg} \cdot \mathrm{m}^{-3}$ in the inner part of the marina. The bloom was almost monospecific, with very few cells of other dinoflagellates, unidentified phytoflagellates and benthic diatom species.

At Sisal the number of cells increased from the entrance of the marina (st. 4) toward its inner part (st. 1): $1.43 \times 10^{5}$ cells $\bullet 1^{-1}$ (st. 4 ), $2.1 \times 10^{6}$ cells $\bullet^{-1}$ (st. 3), $1.54 \times 10^{7}$ cells $\bullet 1^{-1}$ (st. 2 ), and $3.75 \times 10^{7}$ cells $\bullet 1^{-1}$ (st. 1). At st. $5\left(21^{\circ} 9^{\prime} 44.79^{\prime \prime} \mathrm{N}, 90^{\circ} 3^{\prime} 2.98^{\prime \prime} \mathrm{W}\right)$, on the seaside, water temperature was $28.9^{\circ} \mathrm{C}$, salinity was 36.47 and dissolved oxygen was $6.18 \mathrm{mg} \cdot 1^{-1}$. At this station nanoflagellates $\left(1.17 \times 10^{5}\right.$ cells $\left.\cdot 1^{-1}\right)$ and a few benthic diatoms were observed.

\section{Discussion}

The studied species was ascribed to the Peridiniales based on the diagnosis given in Fensome et al. (1993): (a) a peridiniphycidean in which the 1' plate is symmetrical, the left lateral triple junction being essentially level with the right one; (b) there are two antapical plates placed more or less symmetrically about the midventral/middorsal plane. At first sight, the cells resembled the genus Heterocapsa F. Stein or Azadinium Elbrächter et Tillmann (in particular, A. obesum Tillmann et Elbrächter). However, the thecal plate formula distinguishes our species from both Heterocapsa (it has three anterior intercalary plates) and Azadinium (it has three intercalary and six postcingular plates) (Table 1). The tabulation of our species is closest to Kryptoperidinium (a monospecific genus) and Durinskia; both belong to the family Kryptoperidiniaceae (Gottschling et al., 2017). According to Guiry and Guiry (2018), the former has the following tabulation: Po, 3-4', 2a, 6-7”, 5'”, 2"'”. Figueroa et al. (2009) report the plate formula for the strains of $K$. foliaceum from NW Spain as follows: 3', 2a, 7", 4c, ?s, 5'", 2"”. Horiguchi (2004) gives the plate formula for Kryptoperidinium as Po, X, 4', 2a, 7", 5c, 5s, 5'”, 2"', emphasizing that this genus has seven precingular plates and Durinskia has only six. The plate pattern of our species differs from that of $K$. foliaceum in ventral view mainly by a nearly symmetrical 1', a much smaller s.a. that connects with the 1 " plate, the absence of the narrow elongated 7" plate and the wide s.p. that almost reaches the antapex. In addition, our species has a descending cingulum with the ends displaced by its width; in contrast, $K$. foliaceum has no or a slight displacement.

The genus Durinskia Carty et Cox was proposed for Peridinium balticum with a general plate formula: 4', 2a, 6", 5c, 4s, 5'”, 2"” (Carty and Cox, 1986). Our species corresponds to this formula and is very similar to this species in having a descending submedian cingulum and a slightly more expanded and larger epitheca. Also, the most common plate formula for an isolate of $P$. balticum from an inland saline lake in California was described based on an SEM study: Po, X, 4', 2a, 6", 5c, 4s, 5'”, 2"', (Chesnick and Cox, 1985). Currently five Durinskia species have been described: D. agilis (Kofoid et Swezy) Saburova, Chomérat et Hoppenrath (= Gymnodinium agile), D. capensis Pienaar, H. Sakai et T. Horiguchi, the type species D. dybowskii (Wołoszyńska) Carty (=D. baltica, Peridinium balticum), D. kwazulunatalensis N. Yamada, Sym et T. Horiguchi and Durinskia oculata (F. Stein) Gert Hansen et G. Flaim (= Glenodinium occulatum). Durinskia baltica is considered synonymous with $D$. dybowski as the type species (Guiry and Guiry, 2018); however, herein we prefer to use the most widely accepted name, $D$. baltica, following Kretschmann et al. (2018) who separate D. dybowski and D. baltica (in addition, the molecular tree constructed by these authors clearly differentiates between freshwater and marine strains of Durinskia). Among them, the presence of seven precingular plates is a 

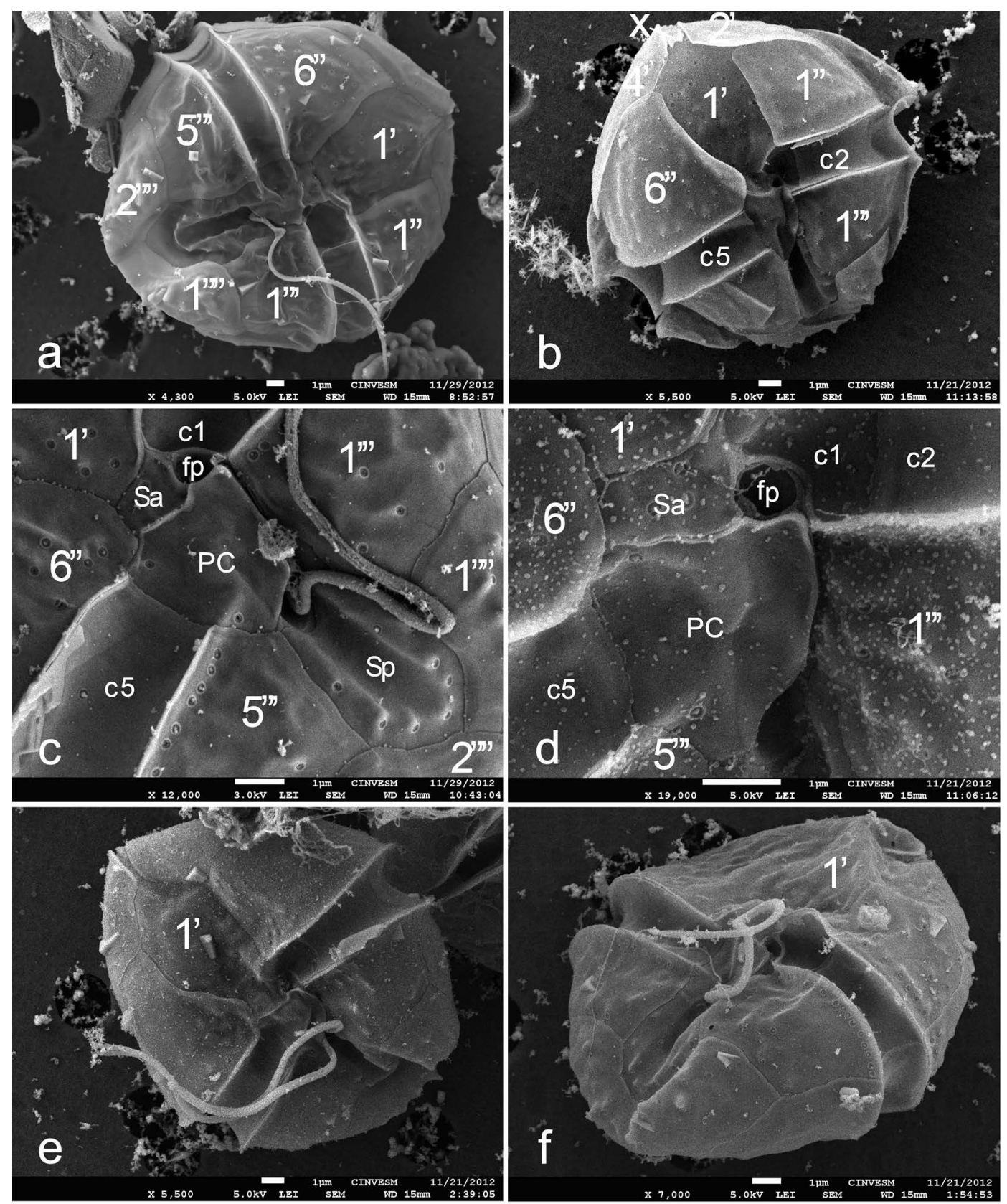

Fig. 6. The Kryptoperidiniaceae species from Yucatan waters under SEM: (a and b) cells in ventral view; (c and d) the sulcal area and adjacent plates in ventral view; (e) planozygote with two longitudinal flagella in ventral view; (f) vegetative cell with one longitudinal flagellum in ventral-posterior-left-side view. Symbols for thecal plates: 1'-4' - the apical plates; 1 "-6" - the precingular plates; 1 '"-5" - the postcingular plates; 1 "' and 2"'” - the posterior plates; $\mathrm{cl}-\mathrm{c} 5$ - the cingular plates; $\mathrm{fp}$ - the flagellar pore; $\mathrm{Sa}$ - the anterior sulcal plate; $\mathrm{Sd}$ - the right sulcal plate; $\mathrm{Sp}$ - the posterior sulcal plate; $\mathrm{X}$ - the canal plate. Scale bar: $1 \mu \mathrm{m}$.

stable characteristic feature only in a sand-dwelling D. agilis (Saburova et al., 2012a); therefore, the difference in the number of the precingular plates between Durinskia and Kryptoperidinium can no longer be considered a discriminative feature. A detailed comparison of some morphological features of our species from Yucatan with related and morphologically similar genera is given in Table 1 .

By comparing both morphological and ecological characteristics, our species is different from all known Kryptoperidinium and Durinskia species. In coastal Yucatan waters, D. capensis has also been 


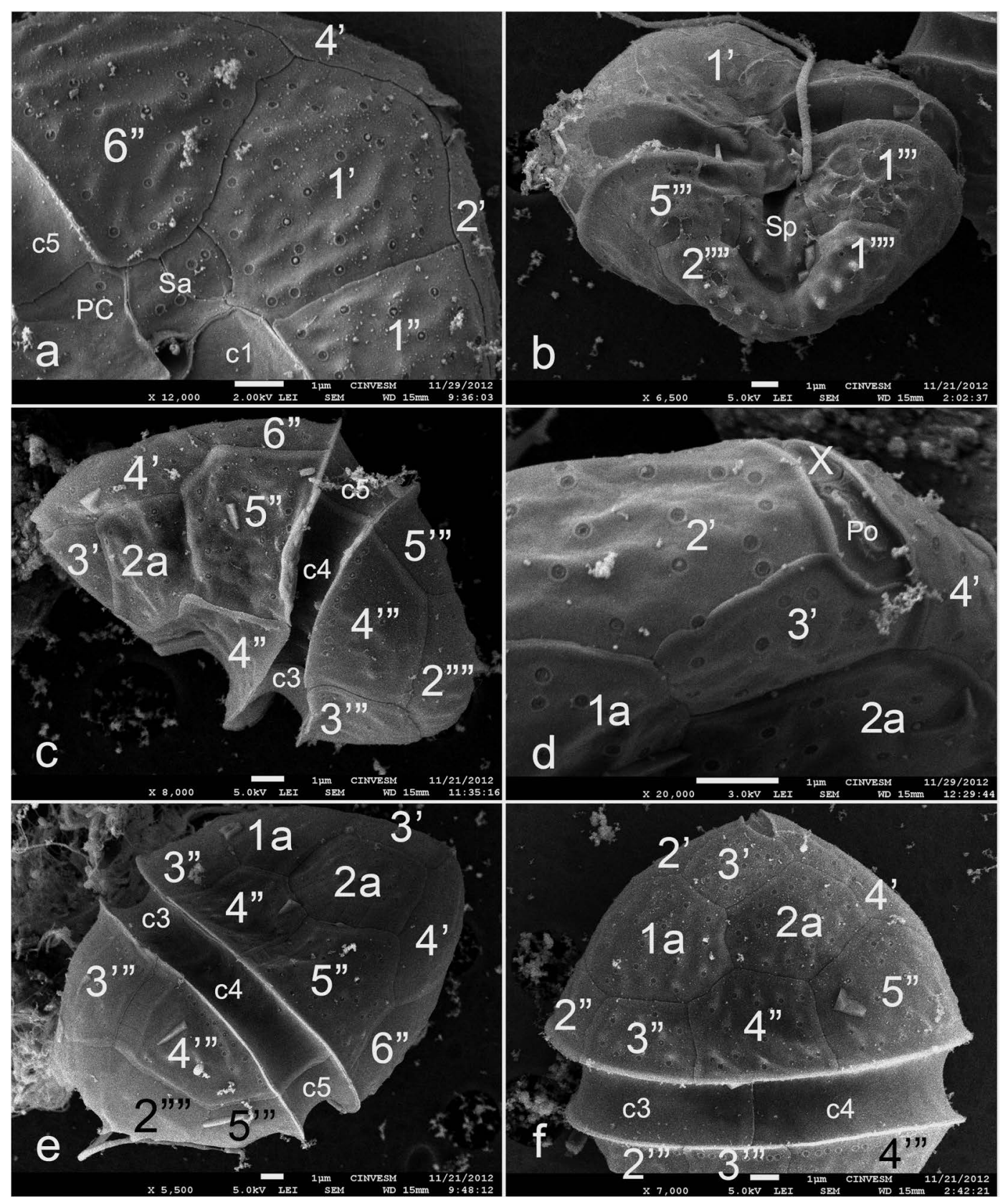

Fig.7. The Kryptoperidiniaceae species from Yucatan waters under SEM: (a) a fragment of the epitheca and adjacent plates in ventral view; (b) cell in posterior-ventral view; (c) slightly deformed cell in dorsal-right-side view; (d) a fragment of the epitheca with the apical pore complex and adjacent plates in apical-dorsal-left-side view; (e) cell in dorsal-right-side view; (f) the epitheca and the cingulum in dorsal view; Symbols for thecal plates: 1'-4' - the apical plates; 1 " -6 " - the precingular plates; $1 \mathrm{a}$ and $2 \mathrm{a}$ - anterior intercalary plates; 1 '" -5 '” - the postcingular plates; 1 "' and 2"” - the posterior plates; 1 -c 5 - the cingular plates; fp - the flagellar pore; $\mathrm{Po}$ - the pore plate; $\mathrm{Sa}$ - the anterior sulcal plate; $\mathrm{Sd}$ - the right sulcal plate; $\mathrm{Sp}$ - the posterior sulcal plate; $\mathrm{x}$ - the canal plate. In Fig. a, a small platelet located between the 1' and Sa plates is noted (this anomaly has probably resulted from the division of the 1' plate). In Fig. a and d, the sparsely dispersed rimmed ejectosome pores are well distinguished. In Fig. b several short teeth are visible. Scale bar: $1 \mu \mathrm{m}$. 
Table 1. Comparison of the Kryptoperidiniaceae species from Yucatan with related and morphologically similar genera.

\begin{tabular}{|c|c|c|}
\hline Taxon & Thecal formula & References \\
\hline $\begin{array}{l}\text { Kryptoperidini- } \\
\text { aceae species }\end{array}$ & Po, cp, X, 4', 2a, 6", $5 c, P C, 4 s, 5^{\prime \prime \prime}, 2^{\prime \prime \prime \prime}$ & present study \\
\hline Durinskia & Po, $\mathrm{X}, 4^{\prime}, 2 \mathrm{a}, 6-\mathrm{7}^{\prime \prime}, 5 \mathrm{c}, 4-6 \mathrm{~s}, 5^{\prime \prime \prime}, 2^{\prime \prime \prime \prime}$ & $\begin{array}{l}\text { Chesnick, Cox, 1985; } \\
\text { Carty, Cox, 1986; Sa- } \\
\text { burova et al., 2012a }\end{array}$ \\
\hline $\begin{array}{l}\text { Kryptoperidini- } \\
\text { um }\end{array}$ & Po, $4^{\prime}, 2 \mathrm{a}, 7^{\prime \prime}, 4(5) \mathrm{c},(>) 5 \mathrm{~s}, 5^{\prime \prime \prime}, 2^{\prime \prime \prime \prime}$ & $\begin{array}{l}\text { Kempton et al., 2002; } \\
\text { Figueroa et al., 2009; } \\
\text { Saburova et al., 2012b }\end{array}$ \\
\hline Blixaea & Po, $3^{\prime}, 2 a, 7^{\prime \prime}, 5 c, 5^{\prime \prime \prime}, 2^{\prime \prime \prime \prime}$ & Gottschling et al., 2017 \\
\hline Unruhdinium & $\begin{array}{l}\text { Po, } 4^{\prime}, 0 a, 6^{\prime \prime}, 5 c, 5^{\prime \prime \prime}, 2^{\prime \prime \prime \prime} \text { or } \\
\text { Po, } 3^{\prime}, 1 a, 66^{\prime \prime}, 5 c, 5^{\prime \prime \prime}, 2^{\prime \prime \prime \prime}\end{array}$ & Gottschling et al., 2017 \\
\hline Azadinium & Po, 4',3a,6",6c,?5s,6"',2"'"' & $\begin{array}{l}\text { Tillmann et al., } 2009, \\
2010,2011,2012 ; \\
\text { Percopo et al., } 2013\end{array}$ \\
\hline Heterocapsa & Po, $X, 5^{\prime}, 3 a, 7^{\prime \prime}, 6 c, 5 s, 5^{\prime \prime \prime}, 2^{\prime \prime \prime \prime}$ & $\begin{array}{l}\text { Iwataki et al., 2003, } \\
2008\end{array}$ \\
\hline
\end{tabular}

observed, but this species differs from our species with its noticeably green chloroplasts and is always epibenthic; in Veracruz, D. capensis has been observed only in surface sediment samples (Okolodkov et al., 2007). Above all, morphologically, our species is similar to the species found in Yemeni coastal waters, the southern Red Sea, identified as K. foliaceaum (Alkawri, 2016); however, it is much smaller: the cells from Yucatan have dimensions 12.5-23.7x 8.7-18.7 $\mu \mathrm{m}$, and the cells from the Red Sea are $30-42 \times 25-35 \mu \mathrm{m}$. We consider the Yemeni species a misidentification: the cells from the Red Sea have an almost symmetrically rhomboid 1' plate and do not have a narrow 7' plate (Fig. $7 \mathrm{E}$ in the publication mentioned above), whereas K. foliaceum has a clearly asymmetrically subtrapezoidal 1 ' plate and a long, narrow 7" plate, with both plates being well distinguished in ventral view (Kempton et al., 2002, Fig. 1; Wolny et al., 2004, Fig. 1 A, B; Figueroa et al., 2009, Fig. 1; Saburova et al., 2012b, Fig. 2 E, F). Until the present, Kryptoperidinium has been considered a monotypic genus. However, there is considerable diversity for the morphology and DNA sequence data, and in the molecular trees two distinct ribotypes of Kryptoperidinium can be distinguished (see: Gottschling et al., 2019).

It is widely known that the species of the family Kryptoperidiniaceae are characterized by the presence of two nuclei: one is a dinokaryon, and the other is a eukaryotic endosymbiont nucleus originated from diatoms (Dodge, 1971; Tomas and Cox, 1973; Tomas et al., 1973; Horiguchi and Pienaar, 1994; Schnepf and Elbrächter, 1999; Kempton et al., 2002; Horiguchi, 2004; McEwan and Keeling, 2004; Imanian and Keeling, 2007; Figueroa et al., 2009; Zhang et al., 2011; Yamada et al., 2017, 2019). Although we did not find the second (eukaryotic) nucleus in the cells from Yucatan, we believe that the cells belong to the family Kryptoperidiniaceae species, thus being related to a monophyletic marine "dinotom" clade that contains diatom-harbouring fucoxanthin-containing dinoflagellates of the genera Durinskia and Kryptoperidinium species, which is supported by molecular evidence (Horiguchi, 2004; Pienaar et al., 2007; Takano et al. 2008; Zhang et al., 2011; Saburova et al., 2012a; Yamada et al., 2017). Kempton et al. (2002) observed a mononucleate bloom isolate in South Carolina (USA) waters caused by a Kryptoperidinium foliaceum. Gottschling et al. (2019) also observed Kryptoperidinium from the western Baltic Sea without an endosymbiont nucleus. Although Durinskia usually has two nuclei (Moestrup and Callado, 2018), in D. capensis the engulfed endosymbiotic diatom nucleus may disappear (Yamada et al., 2019). Thus, based on the number of nuclei, we could not give preference to either of these two genera in identifying the genus.

No doubt, molecular analysis, observation under a transmission electron microscope (to examine the cell ultrastructure) and a light microscope (to examine an eyespot in live cells), and data on the pigment composition could give us valuable information permitting us to ascribe the studied species to genus with certainty. Further studies must reveal more details to confirm or to reject our hypothesis of a Kryptoperidiniaceae affiliation of the species and to ascribe it to a genus or even to a species (creating a new species is a possibility).

As an aside, it is interesting to note that two days before sampling for our study, a specimen of Morelet's crocodile, Crocodylus moreletii (Bibron et Dumeril), endemic to southeastern Mexico, Belize and Guatemala, was captured outside the marina (Gonzalo I. Puerto-Esquivel, pers. comm.); it may have been attempting to escape the bloom. The bloom of the Kryptoperidiniaceae species was observed for the first time in Yucatan waters. In subsequent years, it was occasionally also found eastward from Sisal along the northern Yucatan coast (as Kryptoperidinium cf. foliaceum; MerinoVirgilio et al., 2014). It may represents a recent invasion of the southern Gulf of Mexico from the Caribbean Sea and may prefer semi-enclosed water bodies with the salinity values lower than those of the open sea. In the Gulf of Mexico, another member of 
the Kryptoperidiniaceae that was originally reported as Peridinium quinquecorne, has caused recurrent blooms in the coastal waters in the southwestern Gulf of Mexico (Barón-Campis et al., 2005; AkéCastillo and Vázquez, 2011; Pérez-Morales et al., 2015; Rodríguez-Gómez et al., 2015, 2019; Okolodkov et al., 2016) and also in its southeastern part (Merino-Virgilio et al., 2014).

\section{Acknowledgements}

Ileana Osorio-Moreno, Ana R. Cristóbal-Ramos, Natalia A. Okolodkova and Daniela G. Medina-Eúan (Mexico) are thanked for technical support. Malte Elbrächter (Germany) helped us with valuable advice, and Marcia M. Gowing (USA) kindly improved the English style. We are grateful to the two anonymous reviewers for their valuable critical comments. Patricia Quintana-Owen (Mexico) is thanked for financial support (projects FOMIXYucatán No. 108160 and CONACYT LAB-2009-01 No. 123913, Mexico). IGL is a COFAA fellow.

\section{References}

Aké-Castillo J.A. and Vásquez G. 2011. Peridinium quinquecorne var. trispiniferum var. nov. (Dinophyceae) from a brackishwater environment. Acta Bot. Mex. 94, 125-140.

Alkawri A. 2016. Seasonal variation in composition and abundance of harmful dinoflagellates in Yemeni waters, southern Red Sea. Mar. Poll. Bull. 112, 225-234.

Barón-Campis S.A., Hernández-Becerril D.U., Juárez-Ruíz O. and Ramírez-Camarena C. 2005. Marea roja producida por el dinoflagelado Peridinium quinquecorne en Veracruz, México (oct-nov, 2002). Hidrobiológica. 15 (1), 73-78.

Carty S. and Cox E.R. 1986. Kansodinium gen. nov. and Durinskia gen. nov.: two genera of freshwater dinoflagellates (Pyrrhophyta). Phycologia. 25, 197-204.

Chesnick J.M. and Cox E.R. 1985. Thecal plate tabulation and variation in Peridinium balticum (Pyrrhophyta: Peridiniales). Trans. Am. Microsc. Soc. 104 (4), 387-394.

Daghor L., Hssaida T., Fraikech M., Ennaffah B., Bouthir F.Z., Mimouna A. and El Bouhmadi K. 2015. Impact of environmental disturbances on the dynamics of phytoplankton blooms. Int. J. Adv. Res. 3 (11), 1071-1085.
Dodge J.D. 1971. A dinoflagellate with both a mesocaryotic and eukaryotic nucleus. I. Fine structure of the nuclei. Protoplasma. 73, 146-157.

Fensome R.A., Taylor F.J.R., Norris G., Sarjeant W.A.S., Wharton D.I. and Williams G.L. 1993. A classification of living and fossil dinoflagellates. Sheridan Press, Hanover, PA, USA.

Figueroa R.I., Bravo I., Fraga S., Garcés E. and Llavería G. 2009. The life history and cell cycle of Kryptoperidinium foliaceum, a dinoflagellate with two eukaryotic nuclei. Protist. 160, 285-300.

Gottschling M., Žerdoner Čalasan A., Kretschmann J. and Gu H. 2017. Two new generic names for dinophytes harbouring a diatom as an endosymbiont, Blixaea and Unruhdinium (Kryptoperidiniaceae, Peridiniales). Phytotaxa. 306, 296-300.

Gottschling M., Tillmann U., Kretschmann J., Elbrächter M., Kusber W.-H. and Hoppenrath M. 2019. Glenodinium triquetrum Ehrenb. is a species not of Heterocapsa F. Stein but of Kryptoperidinium Er. Lindem. (Kryptoperidiniaceae, Peridiniales). Phytotaxa. 391, 155-158.

Guiry M.D. and Guiry G.M. 2018. AlgaeBase. World-wide electronic publication. National University of Ireland, Galway, Ireland. [cited on 27 June 2018]. Available from: http://www.algaebase.org.

Herrera-Silveira J.A. 1993. Ecología de los productores primarios en la laguna de Celestún, México. Patrones de variación espacial y temporal. Ph. D. thesis. Universitat de Barcelona, Barcelona, España.

Horiguchi T. 2004. Origin and evolution of dinoflagellates with a diatom endosymbiont. In: Neo-Science of Natural History: Integration of Geoscience and Biodiversity Studies, Proceedings of International Symposium on "Dawn of a New Natural History - Integration of Geoscience and Biodiversity Studies”, March 5-6, 2004, Sapporo, Japan, pp. 53-59.

Horiguchi T. and Pienaar R.N. 1994. Ultrastructure of a new marine sand-dwelling dinoflagellate, Gymnodinium quadrilobatum sp. nov. (Dinophyceae) with special reference to its endosymbiotic alga. Eur. J. Phycol. 29. 237-245.

Horstmann U. 1980. Observations on the peculiar diurnal migration of a red tide Dinophyceae in tropical shallow waters. J. Phycol. 16, 481-485.

Imanian B. and Keeling P.J. 2007. The dinoflagellates Durinskia baltica and Kryptoperidinium foliaceum retain functionally overlapping mitochondria from two evolutionarily distinct lineages. BMC Evol. Biol. 7: 172. Published online: 24 Sept. 2007; doi:10.1186/1471-2148-7-172. 
Imanian B., Pombert J.-F., Dorrell R.G., Burki F. and Keeling P.J. 2011. Tertiary endosymbiosis in two dinotoms has generated little change in the mitochondrial genomes of their dinoflagellate hosts and diatome endosymbionts. PLoS ONE. 7 (8), e43763. doi:10.1371/journal.pone0043763.

Iwataki M. 2008. Taxonomy and identification of the armored dinoflagellate genus Heterocapsa (Peridiniales, Dinophyceae). Plankton Benthos Res. 3, 135-142.

Iwataki M., Botes L., Sawaguchi T., Sekiguchi K. and Fukuyo Y. 2003. Cellular and body scale structure of Heterocapsa ovata sp. nov. and Heterocapsa orientalis sp. nov. (Peridiniales, Dinophyceae). Phycologia. 42, 629-637.

Kempton J.W., Wolny J., Tengs T., Rizzo P., Morris R., Tunnell J., Scott P., Steidinger K., Hymel S.N. and Lewitus A.J. 2002. Kryptoperidinium foliaceum blooms in South Carolina: a multianalytical approach to identification. Harmful Algae. 1, 383-392.

Kretschmann J., Žerdoner Čalasan A. and Gottschling M. 2018. Molecular phylogenetics of dinophytes harboring diatoms as endosymbionts (Kryptoperidiniaceae, Peridiniales), with evolutionary interpretations and a focus on the identity of Durinskia oculata from Prague. Mol. Phylogenet. Evol. 118, 392-402.

Lira B., Parrow M.W. and Tavera R. 2017. Morphology and ecology of freshwater-blooming $\mathrm{Du}$ rinskia baltica (Dinophyceae: Peridiniales) in Xochimilco, Mexico. Microbiol. Res. J. Int. 18, 1-15.

McEwan M.L. and Keeling P.J. 2004. HSP90, tubulin and actin are retained in the tertiary endosymbiont genome of Kryptoperidinium foliaceum. J. Eukaryot. Microbiol. 51, 651-659.

Merino-Virgilio F. del C., Okolodkov Y.B., Aguilar-Trujillo A.C., Osorio-Moreno I. and Herrera-Silveira J.A. 2014. Florecimientos algales nocivos en las aguas costeras del norte de Yucatán (2001-2013). In: Golfo de México. Contaminación, impacto ambiental, diagnóstico y tendencias. 3rd ed. (Eds: Botello A.V., Rendón von Osten J., Benítez J.A. and Gold-Bouchot G.) UAC, UNAMICMYL, CINVESTAV-Unidad Mérida, México, D.F., Mérida, Yuc., México, pp. 161-180.

Moestrup Ø. and Callado A.J. 2018. Dinophyceae. (Eds: Büdel B., Gärtner G., Krienitz L. and Schagerl M.) Süßwasserflora von Mitteleuropa / Freshwater Flora of Central Europe, 6. Springer Spektrum, Berlin, Germany.

Okolodkov Y.B., Campos-Bautista G. and Gárate-Lizárraga I. 2016. Circadian rhythm of a red-tide dinoflagellate Peridinium quadridentatum in the port of Veracruz, Gulf of Mexico, its thecal morphology, nomenclature and geographical distribution. Mar. Pollut. Bull. 108, 289-296.

Okolodkov Y.B., Campos-Bautista G., GárateLizárraga I., González-González J.A.G., Hoppenrath M. and Arenas V. 2007. Seasonal changes of benthic and epiphytic dinoflagellates in the Veracruz reef zone, Gulf of Mexico. Aquat. Microb. Ecol. 47, 223-237.

Percopo I., Siano R., Rossi R., Soprano V., Sarno D. and Zingone A. 2013. A new potentially toxic Azadinium species (Dinophyceae) from the Mediterranean Sea, A. dexteroporum sp. nov. J. Phycol. 49, 950-966.

Pérez-Morales A., Aké-Castillo J.A., Okolodkov Y.B. and Campos-Bautista G. 2015. Florecimientos algales nocivos y eutrofización frente a la costa del Puerto de Veracruz, suroeste del Golfo de México. Revista Digital E-BIOS (UAM-Xochimilco, México, D.F., México). 2 (8), 21-33.

Pienaar R.N., Sakai H. and Horiguchi T. 2007. Description of a new dinoflagellate with a diatom endosymbiont, Durinskia capensis sp. nov. (Peridiniales, Dinophyceae) from South Africa. J. Plant Res. 120, 247-258.

Rodríguez-Gómez C.F., Aké-Castillo J.A., Campos-Bautista G. and Okolodkov Y.B. 2015. Revisión del estudio del fitoplancton en el Parque Nacional Sistema Arrecifal Veracruzano. Revista Digital E-BIOS (UAM-Xochimilco, México, D.F., México). 2 (8), 178-191.

Rodríguez-Gómez C.F., Vázquez G., AkéCastillo J.A., Band-Schmidt C.J. and MorenoCasasola P. 2019. Physicochemical factors related to Peridinium quadridentatum (F. Stein) Hansen (Dinophyceae) blooms and their effect on phytoplankton in Veracruz, Mexico. Estuar. Coast. Shelf Sci. 230, 106412.

Saburova M., Chomerat N. and Hoppenrath M. 2012a. Morphology and SSU rDNA phylogeny of Durinskia agilis (Kofoid et Swezy) comb. nov. (Peridiniales, Dinophyceae), a thecate, marine, sand-dwelling dinoflagellate formerly classified within Gymnodinium. Phycologia. 51, 287-302.

Saburova M., Polikarpov I. and Al-Yamani F. 2012b. First record of Kryptoperidinium foliaceum (Dinophyceae: Peridiniales) from a hypersaline environment in Kuwait, north-western Arabian Gulf. Mar. Biodiv. Rec. 5(e104), 1-7. doi:10.1017/S1755267212000838.

Schnepf E. and Elbrächter M. 1999. Dinophyte chloroplasts and phylogeny - a review. Grana. 38, 81-97. 
Takano Y., Hansen G., Daisuke Fujita D. and Horiguchi T. 2008. Serial replacement of diatom endosymbionts in two freshwater dinoflagellates, Peridiniopsis spp. (Peridiniales, Dinophyceae), Phycologia. 47 (1), 41-53.

Tillmann U., Elbrächter M., Krock B., John U. and Cembella A. 2009. Azadinium spinosum gen. et sp. nov. (Dinophyceae) identified as a primary producer of azaspiracid toxins. Eur. J. Phycol. 44, 63-79.

Tillmann U., Elbrächter M., John U., Krock B. and Cembella A. 2010. Azadinium obesum (Dinophyceae), a new nontoxic species in the genus that can produce azaspiracid toxins. Phycologia. 49, 169-182.

Tillmann U., Elbrächter M., John U. and Krock B. 2011. A new non-toxic species in the dinoflagellate genus Azadinium: A. poporum sp. nov. Eur. J. Phycol. 46, 74-87.

Tillmann U., Soehner S., Nézan E. and Krock B. 2012. First record of the genus Azadinium (Dinophyceae) from the Shetland Islands including the description of Azadinium polongum sp. nov. Harmful Algae. 20, 142-155.

Tomas R. and Cox E.R. 1973. Observations on the symbiosis of Peridinium balticum and its intracellular algae. I. Ultrastructure. J. Phycol. 9, 304322.

Tomas R., Cox E.R. and Steidinger K.A. 1973. Peridinium balticum (Levander) Lemmermann, an unusual dinoflagellate with a mesocaryotic and a eukaryotic nucleus. J. Phycol. 9, 91-98.

Wolny J.L., Kempton J.W. and Lewitus A.J. 2004. Taxonomic re-evaluation of a South Carolina "red tide" dinoflagellate indicates placement in the genus Kryptoperidinium. In: Harmful Algae 2002 (Eds: Steidinger K.A., Landsberg J.H., Tomas C.R. and Vargo G.A.). Florida Fish and Wildlife Conservation Commission, Florida Institute of Oceanography, Intergovernmental Oceanographic Commission of UNESCO, pp. 443-445.

Yamada N., Bolton J.J., Trobajo R., Mann D.G., Dąbek P., Witkowski A., Onuma R., Horiguchi T. and Kroth P.G. 2019. Discovery of a kleptoplastic 'dinotom' dinoflagellate and the unique nuclear dynamics of converting kleptoplastids to permanent plastids. Scientific Reports. 9:10474; doi.org/10. 1038/s41598-019-46852-y.

Yamada N., Sym S.D. and Horiguchi T. 2017. Identification of highly divergent diatom-derived chloroplasts in dinoflagellates, including a description of Durinskia kwazulunatalensis sp. nov. (Peridiniales, Dinophyceae). Mar. Biol. Evol. 34, 13351351.

Zhang Q, Liu G.-X. and Hu Z.-H. 2011. Durinskia baltica (Dinophyceae), a newly recorded species and genus from China, and its systematics. J. Syst. Evol. 49, 476-485.

Address for correspondence: Yuri B. Okolodkov. Instituto de Ciencias Marinas y Pesquerías, Universidad Veracruzana, Calle Mar Mediterraneo 314, Fracc. Costa Verde, C.P. 94294, Boca del Río, Veracruz, Mexico; e-mail: yuriokolodkov@yahoo.com 